\title{
Measurement Methods for Above-ground Site Investigation Programmes according to StandAG (Project "MessEr") - an Overview
}

\author{
Ingo Kock $^{1, \mathrm{a}}$, Michael Jendras ${ }^{1}$, Thorsten Faß ${ }^{1, \mathrm{a}}$, Gerd Frieling ${ }^{1, \mathrm{a}}$, Wolfram Wartenberg ${ }^{1, \mathrm{a}}$, and \\ Karsten Leopold ${ }^{1}$ \\ ${ }^{1}$ Federal Office for the Safety of Nuclear Waste Management (BASE), Wegelystrasse 8, 10623 Berlin, Germany \\ a formerly at: GRS gGmbH, Schwertnergasse 1, 50667 Cologne, Germany
}

Correspondence: Ingo Kock (ingo.kock@bfe.bund.de)

Published: 10 November 2021

\begin{abstract}
In Germany, the site selection process for a repository for high-level radioactive waste is stipulated by the Site Selection Act (Standortauswahlgesetz - StandAG). During the site selection process, the implementer has to identify and propose siting regions. The Federal Office for the Safety of Nuclear Waste Management (Bundesamt für die Sicherheit der nuklearen Entsorgung - BASE) as the responsible federal authority has to review the implementer's proposal and finally the siting regions remaining in the site selection process will be laid down by federal law. The corresponding above-ground site investigation programmes submitted by the implementer will also be reviewed and then determined by BASE. These programmes and subsequent revisions have to be published by BASE in the Federal Gazette ( $\$ 15$ StandAG).

When reviewing as well as determining above-ground site investigation programmes, state-of-the-art science and technology have to be considered - especially in the field of applied measurement methods. For this reason, it is convenient to have a catalogue of relevant and available measurement methods.

This overview shows the findings and results from the project "MessEr", which was carried out by GRS $\mathrm{gGmbH}$ and initiated and funded by BASE (funding code/FKZ 4717F01202).

To derive such a catalogue for the above-ground site investigation within the site selection process the project "MessEr" (Messmethoden für übertägige Erkundungsprogramme gemäß StandAG - Measurement methods for surface-based exploration programmes in accordance with the StandAG) was initiated by BASE. This catalogue should combine two key features: (i) it should be understandable not only for experts but also for interested members of the general public and (ii) it also should provide a basis to evaluate proposed site investigation programmes.

Accordingly, the main task within the project was to compile above-ground measurement methods considering the three host rocks according to the StandAG - rock salt, clay rock and crystalline rock - and to classify them with regard to the kind of investigation, measuring principles and achievable knowledge. In a second step, every single measurement method had to be characterised and described in detail: advantages, disadvantages and efforts, as well as limitations and uncertainties. Furthermore, aspects such as applicability (with regard to the host rock), the combination of different methods and any possible needs of research and development were discussed. For further information, references such as standard textbooks, weblinks, journals or reports from other international repository projects were compiled for each method. The final step of "MessEr" was to evaluate Appendices 1 to 12 to $\S 24$ StandAG ("geoscientific consideration criteria") with respect to their significance and requirements for above-ground site investigation methods. This resulted in three matrices showing the correlations of required parameters and necessary knowledge according to the StandAG with the compiled measurement methods.
\end{abstract}

Kurzfassung. In Deutschland ist das Standortauswahlverfahren für ein Endlager für hochradioaktiven Abfall im Standortauswahlgesetz (StandAG) festgeschrieben. Der mit der Durchführung des Verfahrens beauftragte 
Vorhabenträger hat die Aufgabe, Standortregionen zu bestimmen und vorzuschlagen. Das Bundesamt für die Sicherheit der nuklearen Entsorgung (BASE) als verantwortliche Bundesbehörde prüft diese Vorschläge. Die Standortregionen, die im Standortauswahlverfahren verbleiben, werden schließlich durch die Bundesgesetzgebung festgelegt. Das BASE prüft ebenfalls die entsprechenden, vom Vorhabenträger vorgelegten übertägigen Standorterkundungsprogramme und legt diese fest. Das BASE ist verpflichtet, diese Programme und Änderungen im Bundesanzeiger zu veröffentlichen (§ 15 StandAG).

Bei der Überprüfung und Bestimmung der Programme für die übertägig zu erkundenden Standortregionen muss der neueste Stand von Wissenschaft und Technologie berücksichtigt werden, vor allem im Bereich angewandter Messverfahren. Deshalb ist ein Katalog relevanter und verfügbarer Messmethoden sinnvoll.

Dieser Überblick legt die Ergebnisse des Projekts „MessEr“ dar, das die GRS gGmbH im Auftrag und mit Förderung vom BASE (Förderkennzeichen 4717F01202) durchgeführt hat.

Für die Erstellung eines solchen Katalogs für übertägige Erkundungsprogramme im Standortauswahlverfahren hat das BASE das Projekt „MessEr“ (Messmethoden für übertägige Erkundungsprogramme gemäß StandAG) gestartet. Der Katalog sollte zwei wesentliche Merkmale verbinden: (i) Er sollte nicht nur für Experten, sondern auch für die interessierte Öffentlichkeit verständlich sein und (ii) er sollte eine Grundlage für die Bewertung der vorgeschlagenen Standorterkundungsprogramme liefern.

Es war demzufolge der erste Schritt im Projekt, die übertägigen Messmethoden für die drei Wirtsgesteine nach StandAG - Steinsalz, Tongestein und Kristallingestein - zusammenzutragen und nach Art der Untersuchung, Messprinzipien sowie erzielbaren Erkenntnissen einzuordnen. In einem zweiten Schritt musste jede einzelne Messmethode ausführlich mit Blick auf Vorteile, Nachteile und Aufwand sowie Grenzen und Unsicherheiten beschrieben werden. Fragen wie die Anwendbarkeit (in Hinblick auf das Wirtsgestein), Kombinationsmöglichkeiten unterschiedlicher Methoden und etwaiger Bedarf bei Forschung und Entwicklung wurden ebenfalls erörtert. Für jede Methode wurden Quellen mit weiterführenden Informationen wie Standardlehrbücher, Weblinks, Zeitschriften oder Berichte anderer internationaler Endlagerprojekte zusammengestellt. Der letzte Schritt in „MessEr“ bestand in der Überprüfung der Anlagen 1 bis 12 zu § 24 StandAG (,geowissenschaftliche Abwägungskriterien“) hinsichtlich ihres Stellenwerts und ihrer Voraussetzungen für übertägige Standorterkundungsmethoden. Daraus ergaben sich drei Raster, die Korrelationen zwischen erforderlichen Parametern wie notwendigen Kenntnissen nach StandAG und den zusammengestellten Messmethoden aufzeigen. 